\title{
Ancient Greek Legend in Modern Japanese Literature: “Run, Melos!” BY DAZAI OSAMu
}

\author{
Lija GANTAR \\ University of Ljubljana, Slovenia \\ lija.gantar@gmail.com
}

\begin{abstract}
Dazai Osamu (1909-1948), a modern Japanese writer, wrote "Run, Melos!" in 1940. The short story is a rework of an Ancient Greek legend of Damon and Pythias from the $4^{\text {th }}$ century B.C., which was introduced to Dazai through Schiller's version of the legend, "The Hostage". The legend, based on a true event, represents the perfect friendship and was reworked a number of times by different antique writers. After having been forgotten for a while, it reappeared in the Middle Ages as a fictional story and has gotten many new adaptations from then on. One of them was Schiller's ballad in 1798, which - alongside an anecdote from Dazai's own life - represented the basis for Dazai's story. Even though "Run, Melos!" is not an autobiographical work, Dazai managed to pass his own feelings onto the characters, add some biblical elements, and included a never-before-employed dark twist in the story, thus making his version more realistic than the preceding ones. Despite the distance in time and place between him and the legend, with "Run, Melos!", Dazai managed to retell a Western literature story, making it a part of the Japanese literature as well, adding motifs and themes influenced by his own life, time, and place.
\end{abstract}

Keywords: Dazai; “Run, Melos!”; literature; modern Japanese literature; Ancient Greek legend

\section{Povzetek}

Dazai Osamu (1909-1948), moderni japonski pisatelj, je kratko zgodbo »Teci, Melos!« napisal leta 1940. Gre za predelavo starogrške legende o Damonu in Pitiasu iz četrtega stoletja pred našim štetjem, s katero se je Dazai seznanil preko Schillerjeve verzije legende, »Jamstvo«. Legenda, ki temelji na resničnem dogodku, predstavlja popolno prijateljstvo in je bila mnogokrat predelana $s$ strani različnih starogrških piscev. Za nekaj časa je utonila v pozabo, potem pa se je kot fiktivna zgodba ponovno pojavila v srednjem veku in od tedaj dalje prejela mnogo predelav. Ena od le-teh je bila Schillerjeva balada leta 1798, ki bila temelj za Dazaijevo zgodbo poleg njegove lastne anekdote. Kljub temu, da »Teci, Melos!« ni avtobiografsko delo, je Dazaiju uspelo prenesti na junake svoja lastna občutja, poleg tega pa dodati biblijske elemente in nikdar prej omenjeno temno plat zgodbe, s čimer je svojo različico legende naredil bolj realistično od prejšnjih. Kljub razdalji v času in prostoru med njim in legendo je Dazai z delom »Teci, Melos!« uspel ponovno povedati zgodbo iz Zahodne književnosti, s čimer jo je naredil tudi del Japonske književnosti, obenem pa dodal motive in teme, na katere so vplivali njegovi lastni življenje, čas in prostor.

Ključne besede: Dazai; »Teci, Melos!«; književnost; moderna japonska književnost; starogrška legenda

Acta Linguistica Asiatica, 7(2), 2017.

ISSN: 2232-3317, http://revije.ff.uni-lj.si/ala/

DOI: 10.4312/ala.7.2.51-68 


\section{Introduction}

Dazai Osamu is most known for autobiographical writings about his turbulent life and numerous suicide attempts, such examples being the novels No Longer Human and The Setting Sun ${ }^{1}$. However, Dazai did not write exclusively about his own life, an example being one of his stories, "Run, Melos!", written in 1940.

The story is based on Schiller's ballad "The Hostage", one of the many reworks of the Ancient Greek legend of Damon and Pythias. The legend represents the perfect friendship of a man sentenced to death who wants to delay the execution and be released for the time, and a man who becomes a hostage as a guarantee for his friend's return. Against everyone's expectations, the accused comes back to be executed but ends up being released by the moved king.

Story-wise, Dazai's rework may not make many differences. However, Dazai made some additions to the plot, the most important one being a never-before-employed dark twist. His immutable despair ${ }^{2}$, relationships, and views on Christianity and the society were an important influence on his literary path. Since autobiographical themes like these are a quintessential part of Dazai's literature, one ought to anticipate the possibility that they will play a role in any of his works, including "Run, Melos!"

The changes Dazai made to the plot, compared to Schiller's version and other reworks of the legend throughout the centuries, possibly show how "Run, Melos!" actually consists of many motifs, typical of Dazai - his own feelings, traces of his own life in the form of an anecdote similar to the story, biblical elements, imperfect characters, relationships, etc.

Despite the fact that Dazai's literature might be perceived as pessimistic and dark, his intervention in this particular story actually makes it more realistic and, therefore, more believable. This paper aims to demonstrate how Dazai's life and beliefs collide with the legend of a perfect friendship, making his version quite different from any other rework. First comes a brief discussion on the genesis and evolution of the legend, followed by an in-detail genesis and analysis of "Run, Melos!", as well as its significance today.

\footnotetext{
${ }^{1}$ None of Dazai's works have been translated from Japanese to Slovene, but there is a Slovene translation of The Setting Sun from English, entitled Večerno sonce.

${ }^{2}$ Brudnoy's article in Monumenta Nipponica (1968) is entitled "The Immutable Despair of Dazai Osamu".
} 


\section{Dazai Osamu's life}

Dazai was born in 1909 as Tsushima Shūji ${ }^{3}$ in Kanagi, a town in the Aomori Prefecture, to a fairly wealthy family. As a child, he wasn't very close to his parents but, despite his poor health, did well in school. He started writing fiction in his second year of junior high school (Wolfe, 1990), but did not get support from his family since the head of the Tsushima family, his brother Bunji, "had expressed doubt and disapproval of his continuing literary interests, fearing they would interfere with his studies" (Lyons, 1985, p. 25). In 1927, Akutagawa Ryūnosuke committed suicide, which affected young Shūji as well. It was about that time that he changed completely - he began "cultivating certain fashionable tastes" (O'Brien, 1983, p. 1); started a relationship with a geisha, Oyama Hatsuyo; and took interest in leftist movements and communism. The latter was especially problematic for him since it represented "the contradiction of his own position" (Lyons, 1985, p. 3). His first suicide attempt occurred in 1929, supposedly not so much because of his political interests but mostly due to his failure in school (Lyons, 1985).

In 1930, he moved to Tokyo to study French literature, but soon stopped attending lectures (Gantar, 2017). He had problems getting accustomed to the new city, and staying on good terms with his family who did not approve of his relationship with Hatsuyo. He was forced into an agreement to marry her and never cross the doorstep of his family house (Gantar, 2017), which led to another suicide attempt, this time with another woman. She died and Dazai didn't, which caused him more problems not only with the family but with the police as well. In the end, aged 21 , he had to marry Hatsuyo (Gantar, 2017). Both the marriage and the double suicide scandal left him listless and unproductive, as he states in "Eight Scenes from Tokyo" ("Tōkyō hakkei") (Dazai, 1970b, p. 193):

[私は完全に、無意志であった。再出発の希望は、みじんも無かった。[...] 自分の醜態の前科を、恥じるどころか、幽かに誇ってさえいた。実に、 破廉恥な、低能の時期であった。学校へもやはり、ほとんど出なかっ た。すべての努力を嫌い、のほほん顔でHを眺めて暮していた。馬鹿で ある。何も、しなかった。[...] 遊民の虚無。それが、東京の一隅にはじ めて家を持った時の、私の姿だ。 $]^{4}$

\footnotetext{
${ }^{3}$ All Japanese names are spelled as transliterated using Hepburn's transliteration system for the Japanese language.

4 "I was utterly without a will of my own. I hadn't the slightest desire to start life over again. [...] Far from being ashamed of my criminal record, I was actually rather proud of it. It was truly a time of ignominious imbecility. I attended school only rarely. I spent my days gazing indifferently at $\mathrm{H}$.'s face. I was a fool. I did nothing. [...] The idle nihilist: that was me in my first house in Tokyo." (Dazai, 1988a, p. 144-145)
} 
His first notable story, "Memories" ("Omoide"), was published in 1933. It was around that time that he started using the pseudonym Dazai Osamu. The same year, he joined the literary circle of the Kaihyō magazine, where he met Dan Kazuo, whom he would later become best friends with (Gantar, 2017). Even though he was beginning to succeed as a writer, Dazai still felt strained and depressed. After failing to get a job at the Miyako shinbun newspaper in March 1935, he spent all his money drinking and attempted to commit suicide again, but failed. A month later, he was hospitalized and underwent appendectomy, remaining in hospital for months due to his chronic lung problems (Lyons, 1985). He developed a narcotic addiction but still managed to win second place at the newly established Akutagawa Ryūnosuke's Literary Award (Lyons, 1985). Since he had been expecting to win the award, Dazai considered second place a major failure. Moreover, his addiction to drugs and alcohol, as well as the continuing lung problems caused him to keep spending and borrowing money (Gantar, 2017). Acquaintances managed to put him in a mental institute, which "broke his spirit" (Lyons, 1985, p. 40). After having being released, he realized Hatsuyo had had an affair during his institutionalization. They attempted suicide together and failed, which was followed by their divorce in 1937 (Gantar, 2017).

Dazai stopped writing until the summer of 1938, when he "at last decided irrevocably that he was going to make his career as a writer, and started writing again" (Lyons, 1985, p. 41). Soon after, his family arranged his marriage with Ishihara Michiko, which took place in January 1939 (Gantar, 2017). During the war, Dazai was exempted from military service due to symptoms of tuberculosis. He finally succeeded as a writer, traveled the country, and held lectures at universities even though he had some problems with censorship (Gantar, 2017). He also became a father to his daughter Sonoko in 1940 and son Masaki in 1944. In an attempt to reconnect with his family, Dazai visited Kanagi a few times and was there when the war ended. He returned to Tokyo in 1946 and, despite his literary success, fell into despair again. The same year, he had an affair with Ōta Shizuko and started to write his great postwar novel, The Setting Sun ("Shayō") (Gantar, 2017), which was published the next year to great success. In 1947, he broke up with Shizuko and had an affair with Yamazaki Tomie, while Shizuko and his wife each bore him a daughter - Haruko and Satoko. Stressed from work, his projects, and personal problems, he became an alcoholic in addition to the insomnia and tuberculosis he had already been suffering from (Gantar, 2017). In December 1947, Dazai "spent five days in bed as a result of an accidental overdose of sleeping pills - how accidental, one can only guess" (Lyons, 1985, p. 52). In the spring of 1948, Dazai started writing No Longer Human ("Ningen shikkaku"), which later became one of his most famous works. A month after finishing the novel, Dazai disappeared and was found on what would be his 39th birthday, drowned in a successful suicide attempt with Tomie (Gantar, 2017). 


\section{Dazai Osamu's writing}

"Dazai belonged to what could be referred to as the third generation ${ }^{5}$ of modern Japanese writers" (Lyons, 1985, p. 4). Many writers were members of literary circles, schools, and groups ${ }^{6}$; however, Dazai never belonged to any of them for a longer period of time (Gantar, 2017). As already mentioned, he was in a Kaihyō magazine group for a while. After the war, he was also a member the Buraiha, which literally means "the school of irresponsibility and decadence" (Lyons, 1985, p. 49), with Sakaguchi Ango and Oda Sakunosuke. But the group was not especially active since Oda died a month after the round-table discussion in December 1946, and Dazai himself died a year and a half later (Gantar, 2017).

Despite the fact that Dazai wasn't as involved in literary groups, he did maintain connections with many writers. His best friend Dan was one of them. But Dan did not influence Dazai as much as his mentors did, especially lbuse Masuji (Gantar, 2017). Ibuse, "who spent his time lecturing on the ancient Shinto scriptures" (Keene, 1964, p. 220), had been watching over Dazai's literary path since 1928. He even became the link between Dazai and his family after the move to Tokyo, supporting him at his writing, correcting his early works (Gantar, 2017), and lending him money. Nevertheless, their relationship was not perfect. Among other things, lbuse was one of the people who put Dazai in a mental institution. This might be one of the things Dazai meant when he wrote about "having to be grateful to people who, in some way unknown to himself, had let him down" (Lyons, 1985, p. 65).

Dazai used writing as a tool to help him cope with his trauma, pain, and despair, which are strongly expressed in his autobiographic works (Gantar, 2017). Because of this, he is often named a writer of I-Novel (watakushishōsetsu), a literary genre very popular in Dazai's time but hard to define because of the great differences between individual authors (O'Brien, 1983). The term ${ }^{7}$ usually "refers to stories in which the firstperson narrator or the third-person narrative perspective is clearly identifiable with the

\footnotetext{
${ }^{5}$ As stated by Lyons (1985), the first generation of modern Japanese writers incorporated Western ideas into the literature because the "Western" was perceived as modern. Writers such as Natsume Sōseki also experienced living abroad (Keene, 1985). Literary characters became lonely heroes, but were more realistic than before. The second generation came in 1910s and after, when modernization was perceived as having already happened and themes such as preoccupation with oneself and one's position in the society took over (Lyons, 1985). Typical writers of that generation, such as Akutagawa and Shiga Nagoya, were already famous and influential when the third generation appeared.

${ }^{6}$ Many important writers of the second generation were part of Shirakabaha, a fairly influential literary school around the time Dazai started writing. A literary establishment, bundan, also bore significance in the literary world since it represented "a self-contained institution that produces, supports, and controls both writers and their publishing opportunities" (Lyons, 1985, p. 6).

${ }^{7}$ Hijiya-Kirschnereit (1996) defines the term based on two typical co-existing components, reality and the focal character, in which one can see similarities with the author.
} 
author" (Lyons, 1985, p. 7). Even though Dazai included many aspects of his life into his writing, he did not share much about himself or his works in his essays and letters; he even thought it to be shameful for a writer to be explaining their own work (Ueda, 1976). Therefore, Dazai's I-Novels are the only insight into his thoughts on literature and the role of the writer (Gantar, 2017). Such an example is "Correspondence of Horned Owl" ("Mimizuku tsūshin"), where a character named Dazai claims literature bears little practical use, comparing it to an "airplane that does not fly" (Ueda, 1976, p. 171).

In addition to his own thoughts and experiences, Dazai also relied on other authors and works, as well as newspapers and anecdotes, as a source for his writing (O'Brien, 1983). In his stories, he mentions European writers such as Dostoyevsky, Ibsen, and Baudelaire (Gantar, 2017); and Japanese works as well. One of the latter is "The Sarashina Diary", which served as a source for the main character in Dazai's novel The Setting Sun (Rimer, 1978). He also reworked stories of Asian and Western literature, the latter being the case with the short story "Run, Melos!", a rework of Schiller's ballad (Gantar, 2017). In his reworks, Dazai "made his characters more sympathetic figures than they have been in the original" (Ueda, 1976, p. 149). For instance, they have "bad" traits and weaknesses, as Dazai perceived weakness as "a sign of goodness, not evil" (Ueda, 1976, p. 150). Despite Dazai relying on existing works and not always writing stories that are purely autobiographical, O'Brien (1983, p. 6) claims "Dazai's selfobsession was so intense that he could see in others only a reflection of himself."

Biblical elements are also integrated in Dazai's works, but not always in a typical way. His "confused and varying use of Christian motifs, symbols, and references" (Brudnoy, 1968, p. 460) shows his views on Christianity and God, as well. Dazai dedicated a whole story to Judas Iscariot's betrayal in "I Accuse" ("Kakekomi uttae"), but more often identified himself with Jesus Christ (Gantar, 2017). In his works, Dazai's view on God as a fearful, ruthless judge inside the man is also presented. According to Brudnoy (1968), citing Iriye, such a frightening God does not need a devil for an opposite, and it frightened Dazai a lot since he was always expecting punishment for the evil within himself (Ueda, 1976). As Dazai (1991, p. 448) himself stated in "Villon's Wife" ("Viyon no tsuma"), he understood the fact that he must live despite wanting to die for others, as God's punishment:

[僕はね、キザのようですけど、死にたくて、仕様が無いんです。生れた 時から、死事ばかり考えていたんだ。皆のためにも、死んだほうがい いんです。それはもう、たしかなんだ。それでいて、なかなか死ねな い。へんな、こわい神様みたいなものが、僕の死めのを引きとめるので 
す。[...] おそろしいのはね、この世の中の、どこかに神がいる、という 事なんです。いるんでしょうね?] $]^{8}$

Dazai's persistent feeling of guilt is shown in that story, as well as in the beforementioned "I Accuse", in which Judas is unable to prove his innocence and is, therefore, only more aware of his guilt and utter imperfection (Brudnoy, 1968). Nevertheless, Dazai's characters do not seek salvation, even though they do repent for their weaknesses (Gantar, 2017), which makes them more similar to Judas than Christ or any other apostle (Ueda, 1976).

\section{Genesis of "Run, Melos!"}

Dazai published the short story "Run, Melos!" in May 1940 (Gantar, 2017), stating it was based on "an ancient legend and a poem by Schiller" (Dazai, 1988b, 135) at the end of the story. The legend mentioned is the Ancient Greek legend of Damon and Pythias, a story about friendship in which one friend risks his life for another. The poem mentioned above is Schiller's rework of the legend, "The Hostage", written in 1798.

Dazai mostly relied on the Japanese translation of the poem, "Hitojichi"9 (Gantar, 2017). As stated by Ishibashi Kunitoshi (2014) in his essay “Dazai Osamu's 'Run Melos!' and Schiller's 'The Hostage'", Dazai accessed the translated version of the poem through a new edition of Schiller's anthology.

The ballad was published in 1937, three years before Dazai's short story was written (Gantar, 2017). As was discovered by Kakuta Ryojin (Ishibashi, 2014, 55), Dazai did not just repeat the story:

\section{[「走れメロス」と小栗訳「人質」のつながりを発見した角田旅人も指摘 するように、「人質」の少なからぬ部分を太宰治は引用・転用している のである。 $]^{10}$}

\footnotetext{
8 "I must seem a horrible character to you, but the fact is that I want to die so badly I can't stand it. Ever since I was born I have been thinking of nothing but dying. It would be better for everyone concerned if I were dead, that's certain. And yet I can't seem to die. There's something strange and frightening, like God, which won't let me die. (...) But what frightens me is that somewhere in the world there is a God. There is, isn't there?" (Dazai, 1985, p. 412)

${ }^{9}$ The title of the Japanese translation, as well as the English, refers a person who is a hostage, while the original title, "Die Bürgschaft", actually means "guarantee", bringing the focus not to one of the two friends but rather to the act itself.

10 "As pointed out by Kakuta Ryojin, who discovered the connection between "Run, Melos!" and Oguri's translation, "Hitojichi", there is a considerable amount of parts of "Hitojichi" that Dazai cited or diversified." (Trans. L.G.)
} 
Interestingly, the elements that only appeared in the translation can also be observed in Dazai's work. He had also had to read the annotations, because he could not have been able to know the names of characters such as the king and Selinuntius (Ishibashi, 2014). Remaking the poem, Dazai also expanded the story, adding more information about the characters and circumstances (Gantar, 2017).

Since Dazai's works usually consist of darker themes, it is interesting to note that he kept the original happy ending of the legend. One of the reasons was probably the fact that the story was not an autobiographical work, even though it incorporated friendship and the need for it like Dazai's earlier works (O'Brien, 1983). Nevertheless, Dazai did add a darker note to the story, which Vardaman (1987, p. 249) claims to be because "Dazai possibly found Schiller's character to be too perfect to be believable".

Another reason for the change probably lies in Dazai's own experiences, as is common in his works. The anecdote from a more turbulent part of Dazai's life is actually similar to the story of the Ancient Greek companions. Just like one of the friends from the legend is taken hostage instead of the other, Dan Kazuo once had to remain at an inn in Atami after Dazai had spent all his money there and promised to return and pay his debts after borrowing from Ibuse. As opposed to the legend, Dazai didn't return for a few days, making Dan pay by himself to be able to leave and search for his friend. He found Dazai at Ibuse's place playing shōgi, too ashamed to ask his mentor for money (Gantar, 2017).

In addition to the anecdote, there are also other connections between the story and Dazai. For example, "Ono Masamfumi sees in the Dazai version a reflection of Dazai's own emotional world" (Vardaman, 1987, p. 249). The main character, Melos, becomes more similar to Dazai in the rework. Just as Melos's freedom depends on his friend being a hostage, Dazai remained dependent on his family for most of his life (Gantar, 2017) - not only financially, since the relationship with his kin burdened him until his death. He was strained by expectations, as is Melos, as well. The same applies to Dazai's feelings of guilt and letting people down, both being present in the abovementioned anecdote.

Additionally, Dazai felt he had been disappointed and let down, which affected him greatly (Gantar, 2017). He names many instances of "betrayal" in his life, including his friends putting him into a mental institution and Hatsuyo revealing "she was not the pure creature he had thought her" (Lyons, 1985, p. 33). As he was the betrayed and the betraying one throughout his whole life, Dazai probably could not believe the ideal relationship between two people portrayed in Schiller's ballad could exist (Gantar, 2017).

Despite the fact that Dazai made the story more realistic and in tune with his own emotions, he kept the original positivity of the story. Melos, by contrast to Dazai, manages to overcome the obstacles and live up to the expectations. The happy ending 
"In Dazai's story, if not in his life" (Vardaman, 1987, p. 249) may be indicative of Dazai's hopes of achieving the same as Melos, especially because he wrote the story in 1940 when his life finally took a turn for the better (Gantar, 2017).

\section{The legend of Damon and Pythias}

Before analyzing Dazai's short story "Run, Melos!", it is necessary to understand the background of its theme, the legend of Damon and Pythias.

The legend is based on two disciples of philosopher Pythagoras, who lived on Sicily around the $4^{\text {th }}$ century B.C., when the ruling king was the tyrant Dionysius (Gantar, 2017). The first to write about their story was Aristoxenus, who lived at the same time as Damon and Pythias. Aristoxenus's friend, a historian named Philistus, also wrote about the two friends, but according to the article in San Francisco Times ("Different Accounts That History Offers Us Concerning the Story of Damon and Pythias", 1902), both records of the story have been lost for over a thousand years.

The oldest known record of the story is a mention in Marcus Tullius Cicero's De officiis, written in the $1^{\text {st }}$ century B.C. In his version, is it not stated who the accused was and who the hostage. The reason for the postponement of the execution is the wish to put his loved ones in the care of others (Cicero, 1913). Cicero mentions the story once again and focuses on the king who strongly believes that Pythias will care more for his life than the friendship, and lets him go to prove himself right (Gantar, 2017). Despite the fact that this is the first known existing version of the story, it already seems like it was meant as a lesson and example for others to follow (Gantar, 2017).

After Cicero, Diodorus Siculus, also in the $1^{\text {st }}$ century B.C., wrote his own version, adding information about the accused. Pythias was sentenced to death because he had been plotting against the tyrant. A few years after Siculus, Valerius Maximus rewrote the story, including an important addition - the accused did not show up until the last minute. Gaius Julius Hyginus picked up this detail and brought the gradual tension even further by adding an obstacle on the accused's way back to Syracuse. His character has problems crossing the river and almost does not make it in time to save his friend. Hyginus is also the first known author to change the friends' names from Damon and Pythias to Merus and Selinuntius. After Hyginus, a few other authors mention the legend, as well. Some versions were also translated from Greek into Latin and viceversa, and later on also into other languages. In each version, small changes and additions made the original true story lose its historical value and, as such, writers soon took it over from the historians (Gantar, 2017).

Despite the popularity of the legend before, it remained ignored and forgotten for about a thousand years, reappearing in the fourteenth century in Gesta Romanorum (Raschen, 1919). The main characters in this version are thieves, but otherwise the 
story remains unchanged. Similarly, in the many reworks following Gesta Romanorum, the friends' occupations, names, backgrounds, the reason for the delay, and other details are changed. Soon after its reappearance, the legend was also translated into French in 1347 and 1350. On the basis of the latter translation, the English version appeared as well, aiding the legend's spread and rise in popularity (Raschen, 1919).

\section{Schiller: "The hostage"}

"The Hostage" ("Die Bürgschaft"), a 20-stanza-long ballad based on the legend of Damon and Pythias, was written in 1798 by Johann Christoph Friedrich von Schiller.

Schiller first read about the legend in Hyginus's stories. According to his correspondence with Goethe, who sent him the book in December 1797, Schiller thought the characters of the story to be made up. He was almost done writing a ballad about the legend in August 1798 (Schiller \& Goethe, 1845, p. 136). In September, he sent "The Hostage" to Goethe, asking for his opinion, which was positive with the exception of the parts Goethe thought were "physiologically inconsistent and therefore hard to imagine" (Schiller \& Goethe 1845, p. 140).

The story of the ballad is similar to Hyginus's. Merus plans to kill the king but is caught and sentenced to death by crucifixion. He wants a delay of three days to attend his sister's marriage, as is the case with Hyginus's character (Gantar, 2017). The main changes take place when Merus is returning to Syracuse to be executed. Instead of Hyginus's overly flooded river, Schiller's character encounters a broken bridge. Two additional obstacles are also added to his journey - he confronts three bandits and has to kill one of them, after which he soon becomes too tired to continue walking. He cries to Zeus again and a stream starts flowing from the rock. Melos drinks the water and gets his strength back, barely managing to return in time. On the last part of his journey, he encounters a few people talking about the hostage, which further intensifies the tension as he decides to die, even if he arrives too late: "Und ist es zu spät, und kann ich ihm nicht, / Ein Retter, willkommen erscheinen, / So soll mich der Tod ihm vereinen." (Schiller, 1994-1999a) ${ }^{11}$. Selinuntius's name is not mentioned, nor does the story imply his feelings or thoughts, which is a deviation from Hyginus's version.

11 "Too late! what horror hast thou spoken! / Vain life, since it cannot requite him! / But death with me can yet unite him" (Schiller, 1994-1999b). 


\section{Dazai: “Run, Melos!”}

Dazai Osamu's version of the story is similar to Schiller's but, as mentioned before, Dazai's own feelings and the anecdote made "Run, Melos!" somewhat different from the previous versions of the legend.

Dazai's character, Melos, is a shepherd who visits Syracuse to buy all that is necessary for his sister's wedding and meet his childhood friend, Selinuntius, while there (Gantar, 2017). He is "a simple man" (Dazai, 1988b, p. 116), so when he sees the fear and terror in the city, he decides to kill the tyrant who is putting people to death. $\mathrm{He}$ is caught and has a deep conversation with the king about human nature before being sentenced to death. Dionysus states that every man is selfish and arrogant, while Melos claims that doubting others is the most shameful evil (Gantar, 2017). To prove to Melos that he is right, the king lets him go in exchange for a hostage and even offers him a deal (Dazai, 1970, p. 171):

[三日目には日没までに帰って来い。おくれたら、その身代りを、きっと 殺すぞ。ちょっとおくれて来るがいい。おまえの罪は、永遠にゆるして やろうぞ。[...] はは。いのちが大事だったら、おくれて来い。おまえの 心は、わかっているぞ。] $]^{12}$

Melos returns home and persuades his sister to marry the next day without revealing his fate to anyone (Gantar, 2017). At dawn on the third day, he leaves home and is in a fairly good mood until he comes to the broken bridge. After managing to cross the river, he is attacked by mountain bandits who may have been sent out by the king (Dazai, 1988b). He kills them after not being able to get away with talking. A while later, he loses his ability to walk due to dehydration and fatigue. Pondering the situation, he starts feeling guilty and hopeless for he will most likely not be able to save Selinuntius, even though he is willing to become a hostage and prepared to sacrifice his own life for the sake of their friendship. The fact that the king will prove his point that all men are selfish pains Melos deeply. He does not beg Zeus for mercy, but Selinuntius, thankful and full of regret: "Forgive me, Selinuntius. You were constant in your trust in me. Nor have I deceived you. You and I were good, true friends. [...] Even now, you patiently await my return. Ah, I know you are waiting. Thank you, Selinuntius. You trusted me, and trust between friends is life's greatest treasure." (Dazai, 1988b, p. 127). Then suddenly, just for a moment, he considers himself surviving as not the worst possibility since righteousness, trust, and love probably are not worth much (Dazai, 1970, p. 179):

\footnotetext{
12 "You are to return before sundown of the third day. Should you be late, the hostage shall die. Yes, you would do well to come a bit late: you will be absolved forever of your crime. [...] Ha, ha! Be late, if you value your life. I know your heart." (Dazai, 1988b, p. 118-119).
} 
[君と一緒に死なせてくれ。[...] いや、それも私の、ひとりよがりか？あ

あ、もういっそ、悪徳者として生き伸びてやろうか。村には私の家が在

る。羊も居る。人を殺して自分が生きる。それが人間世界の定法ではな かったか。 $]^{13}$

Amidst those thoughts, a stream starts running from a crack in the rocks. Melos drinks it and his mind clears up. He continues his journey back, thinking only of his friend's unconditional trust on his return (Gantar, 2017). Desperate to arrive in time, he runs pushing people away, coughing blood, and not listening to Selinuntius's apprentice, Philostratus, that it is too late. He barely arrives in time and makes his way through the cheering crowd. Instead of a happy reunion, Melos breaks down crying and asking for punishment, since he betrayed his friend with the thought of not returning in time. Selinuntius punches him and demands the same for himself, since he also had a moment of doubt. Melos returns the favor of punishing his friend and they finally embrace, tears streaming down their faces. At the end, the king acknowledges his being wrong and wants to be their friend, since people seem to be worth the trust: "You have subdued my heart. Trust between men is not just an empty illusion. I, too, would be your friend." (Dazai, 1988b, p. 133).

As can be seen in the summary above, the main change Dazai made was to Melos's and Selinuntius's thoughts, which they themselves consider as betrayal, and the guilt that followed. Friendship, which has been the essence of the legend since its origin, remains the most important theme but in a completely different aspect. While it is still a story of the ideal friendship portrayed in Schiller's ballad, Dazai's characters turn out to be imperfect, digressing from the legend that has been presenting their friendship as a model example (Gantar, 2017).

Compared to Schiller's characters, who are either good (Merus and Selinuntius) or bad (the king) (Gantar, 2017), Dazai's characters are never unilateral. His King Dionysus is not really an evil tyrant, for he reveals his pitiable suffering ("What do you know of my pain and solitude?" (Dazai, 1988b, p. 117)) in the conversation he has with Melos at the beginning of the story. Similarly, Dazai demythologizes Melos's character of a brave, immensely loyal friend (Gantar, 2017). Dazai's Melos is aware of his own weakness and is scared of dying, which is why he "betrays" his friend and in this dark moment becomes an immoral, dishonorable traitor. Therefore, after his moment of weakness passes, he tries so hard to not only save his friend, but also to "perform his 'duty' and maintain his honor" (Vardaman, 1987, p. 247).

The betrayal, which is Melos momentarily favoring survival over keeping a promise and saving his friend, is definitely the biggest deviation from "The Hostage". Schiller's

13 "Let me die with you. But have I the right? Should I not live on, in corruption and wickedness? I have my home in the village. I have my sheep. [...] We kill others that we may live. That is the way of the world." (Dazai, 1998b, p. 128). 
character even decides to die in case he returns late, just so he could prove to the king his faith in the friendship (Schiller, 1994-1999a). Dazai's Melos appreciates Selinuntius's sacrifice but, in that one moment of doubt, he does not treasure it to the point where he would want to die regardless of the outcome. Moreover, he understands that he would not be late because he wished so and, therefore, it would be a waste to die even if it meant being called a traitor and a bad friend. He feels a shameful life, obtained through Selinuntius' sacrifice, is worth more than dying an unnecessary death after having already lost a friend. He is not selfish, he is human (Gantar, 2017). He is prepared not to be able to prove the king wrong, which he states himself would be more painful than death (Dazai, 1988b). Choosing to live as a traitor, ironically, makes him lose the arrogance of the man who always wants to prove himself right - the arrogance that the king assigned to all men and, on the basis of which he hates them. Melos wakes up from these thoughts after drinking the water, and he is more determined than ever to return and save his friend (Gantar, 2017).

By contrast, Dazai does not disclose how Selinuntius beats his own moment of weakness. His side of the story - aside from mentioning his being a faithful, patient friend - was mostly omitted in the previous reworks of the legend. To intensify his perfect loyalty, many authors kept him silent, which is the case with Schiller's "The Hostage" as well. Dazai's "Run, Melos!" makes Selinuntius nod and take the place of a hostage as well, but takes a different turn at the end of the story when Melos returns and it seems like the only thing left is a happy ending, quintessential for the legend as shown in the previous retellings. Melos, who has been suffering ever since the realization that he betrayed Selinuntius in his moment of weakness, confesses his $\sin$ on the spot. But what is even more unexpected is his friend's confession that follows. As the whole story mostly consists of Melos' thoughts and trials, Selinuntius remains in his shadow. But in the end, even Dazai's hostage is not perfect. He is just as human as Melos, and was at some point stricken by the thought that Melos may betray him:

\section{“[メロス、私を殴れ。(...) 私はこの三日の間、たつたー度だけ、ちらと} 君を疑った。生れて、はじめて君を疑った。]” (Dazai, 1970, p. 183) ${ }^{14}$.

Nevertheless, he kept his feelings for himself, as is evident from Philostratus's words: "My master believed in you. (...) His faith in you was unshaken until the end." (Dazai, 1988b, p. 131). But just once, Selinuntius, too, considers the value of his life in opposition to dying for his friend's crime. Despite that, he still remains faithful in his actions, not saying a word, defeating his own weakness by stubbornly claiming Melos will return (Gantar, 2017). Dazai does not mention whether Selinuntius is physically weak in his moment of doubt or not, nor does he state what precisely happens to him during his time as a hostage expect for being mocked. That being put aside, both

14 "Hit me. (...) Once during the past three days, I doubted you. Just once, but for the first time in my life." (Dazai, 1988b, p. 133). 
friends' doubts are similar, especially in the aspect that both of their sins remain a thought and do not change the outcome. No one would know about it if the friends did not confess to each other, and their doubts were dismissed before there could be any actual consequences (Gantar, 2017).

The theme of honesty and trust comes into play with the friends' trial and in the moments of doubt, while those two are self-evident in Schiller's case. The theme of friendship also holds a different meaning in each work. Vardaman (1987, p. 247) states that the friendship in Schiller's ballad "has no psychological or ethical motivation; it is pure ideal", while the friendship of Dazai's Melos and Selinuntius represents an entirely different, more realistic view of the subject. In contrast to Schiller's characters, who define impeccable friendship by never doubting each other at all, Dazai's friends do doubt each other at some point, but are able to get through the dark moment and carry on for the sake of their bond.

Despite the fact that the moment of doubt does not alter the events of the story and all ends well, both friends suffer from guilt, which is a prominent theme in Dazai's works (Gantar, 2017). Selinuntius endures in silence, awaiting either his own death or his friend's return, while Melos feels immense guilt for the remainder of his way to Syracuse, and even after saving Selinuntius. Neither of them is relieved of the guilt until they confess their weakness and feel their sins forgiven after taking a strike to the face. Their reunion is not an immediate embrace with tears of joy, but rather a reunion of two broken men who have played their parts until the very end but betrayed themselves and each other in the process, which is why they can only embrace each other once they are relieved from their guilt (Gantar, 2017).

In opposition to Selinuntius's silent wait even after the moment of doubt, Melos becomes not only full of guilt but also insane as he runs back to Syracuse. His insanity can be observed from the moment he drinks the water from the stream - he runs as though he were ten times faster than the setting sun (Dazai, 1988b); as if driven by an unnatural, boundless force while thinking of nothing but his friend's trust (Gantar, 2017). He loses his humanity, running without feeling pain or fatigue, and despite coughing blood. He does not care about others anymore, pushing people over and kicking animals in his way (Gantar, 2017). He does not even care about appearances and strips off almost all his clothes (Dazai, 1988b). As stated in his dialogue with Philostratus, who tries to persuade him to stop running as it is probably too late, Melos says: 


\section{[それだから、走るのだ。信じられているから走るのだ。間に合う、間に} 合わぬは問題でないのだ。人の命も問題でないのだ。私は、なんだか、 もっと恐ろしく大きいものの為に走っているのだ。] (Dazai, 1970, p. 182) ${ }^{15}$

Philostratus replies with interesting words: "Ah, it is madness that drives you then?" (Dazai, 1988b, p. 131). The madness mentioned is Melos's sheer determination to be worthy of his friend's trust and at least try to fulfill his promise, knowing their friendship to be the most precious thing he will ever have. Even the life with his family that he loved so much just a day ago is suddenly worth nothing. For Melos, there is no future or past. There is just the moment of running, more necessary than life. Only when he runs is he worthy of the faith and friendship - no matter the outcome (Gantar, 2017).

Another addition Dazai made in his rework of the legend is the significance of music and sound as opposed to silence. It does not hold much importance to the general story, but it does deepen certain contrasts in it (Gantar, 2017). In the very beginning, Melos is described as "a mere shepherd [...] who spent his days playing his flute" (Dazai, 1988 b, p. 114). He misses music in the silent, empty streets of Syracuse, and enjoys singing and watching people dance at his sister's wedding. He also sings in the first part of his return to the city to calm himself down (Dazai, 1988b). The sound of the stream wakes him from the moment of doubt, so that he can drink the water and carry on. Afterwards, he is unable to scream from the distance to save his friend, and Selinuntius almost gets executed in his stead. By contrast, his voice and words save him from his despair when confessing his sin to Selinuntius. On these grounds, music not only expands Melos's character, but also adds to the atmosphere of the story. While sounds and music represent positivity and brightness, silence usually intensifies the tension and is present when the situation is not good (Gantar, 2017).

Another characteristic typical of Dazai's works that appears in "Run, Melos!" is the presence of biblical motifs; however, his knowledge of the Holy Bible is vague (Gantar, 2017) and, as such, it makes it hard to determine whether these elements are deliberate or not. Melos does resemble King David from the Old Testament in many aspects - both of them are shepherds who play an instrument and use it to comfort someone (in Melos's case, himself; while David helps king Saul chase away the evil spirit) (Gantar, 2017). Moreover, Melos paraphrases Jesus's words from the Gospel of Mark (14,38 New International Version), "[...] The spirit is willing, but the flesh is weak", twice, both times implying that the weak body is causing the spirit to suffer as well, referring to his fatigued self, lying on the ground. Furthermore, Melos being a shepherd also bears resemblance to Jesus Christ. As the latter takes care of his sheep (the people)

15 "I run because of that faith, that trust. Whether I make it in time is not the question. Nor is it merely a question of man's life. I am running because of something immeasurably greater and more fearsome than death!" (Dazai, 1988b, p. 131). 
and saves them from damnation, so does Melos try to save the people of Syracuse from a tyrant, as well as trying to redeem the king's soul by displaying true friendship to him (Gantar, 2017). Selinuntius, being prepared to die on the cross for the sake of someone else, could also have been a biblical element, but it is not considered one since crucifixion appears as a means of execution in many other versions of the legend (Gantar, 2017).

It is unclear whether Dazai knew about other reworks of the legend than Schiller's "The Hostage". There are a few details that appear in "Run, Melos!" that are absent from the ballad but present in other versions. For instance, Dionysus was not a solely evil character until Dazai's rework, since he was also lonely and had trust issues in Cicero's version (Gantar, 2017). Schiller also omitted the detail with people dying because of the king, which was mentioned by Hyginus, so the latter might have been Dazai's source for this detail. However, the breadth of his knowledge of literature is believed to have been limited, so any similarity to the reworks of the legends other than Schiller's might be incidental (Gantar, 2017).

\section{The contemporary significance of "Run, Melos!"}

Dazai, as well as the short story "Run, Melos!", are still relevant today. The story is a part of the second-year curriculum in Japanese middle schools (Gantar, 2017). The reason for lecturing children on this exact story is probably because its theme is less dark and more children-appropriate than the majority of Dazai's works, while at the same time bringing his most prominent themes and motifs into the forefront.

Dazai is often mentioned alongside Akutagawa, who also rewrote existing literary works by making deviations without ruining the original quality of the stories (Gantar, 2017). He and Dazai both had to combine the original, often written in a non-Japanese narrative style, with their own (Gantar, 2017). In the case of "Run, Melos!" and Dazai's other works, the story starts with an intriguing beginning, but later includes long monologues that can interrupt the flow of the story (Ueda, 1976) or would do so if Dazai did not use very short sentences to reduce the tension (Gantar, 2017). According to Ueda (1976, p. 169), "Dazai's style is far more spontaneous than that of any other modern Japanese writer of the first rank," which is another argument as to why he should be considered as one of the greatest writers of his time.

"Run, Melos!" is a popular basis for non-literary adaptations, as well. It was adapted into a TV drama in 1955, and later on into three animes, two being adaptations for younger audiences. In 2013, "Run, Melos!" was staged as a theater play (Gantar, 2017). 


\section{Conclusion}

At first, "Run, Melos!" does not seem to be Dazai Osamu's typical short story, considering how his works often depict themes of suicide, despair, and troublesome relationships, mostly based on his life. Nonetheless, even though it is a retelling of an Ancient Greek legend of Damon and Pythias, based on Schiller's version, motifs that are most typical of Dazai's literature are included in "Run, Melos!".

Dazai changed the characters by broadening their personalities, and by making the two main characters less perfect and more realistic. Instead of an ideal friendship, Dazai managed to present a friendship of two realistically imperfect people that ultimately wins despite the friends' weaknesses, struggles, and despair. Instead of unwavering trust, Dazai's friends show their loyalty to each other by holding on through the moments of doubt. Dazai's story also includes biblical elements that correspond with Dazai's views on Christianity, as well as musical motifs that emphasize the flow of the story.

Since its publication in 1940, the many adaptations are indicative of both the popularity and the topicality of this Dazai story in the past and the present, which is most likely why his literature is being taught in Japanese schools alongside Akutagawa's.

"Run, Melos!" represents a typical Dazai story in an atypical way, connecting the Western and Ancient Greek literature to Japanese modern literature. As such, it is one of the stories that make Dazai one of the greatest Japanese writers of the modern time.

\section{References}

Brudnoy, D. (1968). The Immutable Despair of Dazai Osamu. Monumenta Nipponica, 13(3-4), 457-474. Retrieved from http://www.jstor.org/stable/2383500

Cicero, M. T. (1913). De Officiis. With An English Translation. (W. Miller, Trans.). Massachusetts, London, England: Cambridge, Harvard University Press. Retrieved from http://www.perseus.tufts.edu/hopper/text?doc=Cic.+Off.+pos\%3D3.45\&fromdoc=Perse us\%3Atext\%3A2007.01.0048

Dazai, O. [太宰治] (1970a). Hashire Merosu [走れメロス]. In Hashire Merosu [走れメロス] (p. 167-184). Tokyo [東京]: Kadokawa bunren [角川文連].

Dazai, O. [太宰治] (1970a). “Tōkyō hakkei” [東京八景]. In Hashire Merosu [走れメロス] (p. 185-220). Tokyo [東京]: Kadokawa bunren [角川文連].

Dazai, O. (1988a). Eight Scenes from Tokyo. In Run, Melos! and other stories (p. 135-177). (R. F. McCarthy, Trans.). Tokyo: Kōdansha.

Dazai, O. (1988b). Run, Melos!. In Run, Melos! and other stories (p. 114-134). (R. F. McCarthy, Trans.). Tokyo: Kōdansha. 
Dazai, O. (1985). Villon's Wife. In D. Keene (ed.), Modern Japanese Literature: from 1868 to present day. New York: Grove Press.

Dazai, O. [太宰治] (1991). Dazai Osamu (chikuma nihon bungaku zenshū) [太宰治 (ちくま日 本文学全集)]. Tokyo [東京]: Chikuma shobō [筑摩書房].

Different Accounts That History Offers Us Concerning the Story of Damon and Pythias. (3. August 1902). San Francisco Call. Retrieved from https://cdnc.ucr.edu/cgi-bin/cdnc?a=d\&d=SFC19020803.2.130.4

Gantar, L. (2017). Kratka zgodba Dazaija Osamuja na ozadju Zahodne literature (Diplomsko delo). Filozofska fakulteta, Ljubljana.

Goethe, J. W. von, Schiller, F. (1845). Correspondence between Schiller and Goethe. From 1794 to 1805. Volume 1. New York and London: Wiley and Putnam. Retrieved from https://archive.org/details/correspondenceb00schigoog

Hijiya-Kirschnereit, I. [イルメラ・日地谷=キルシュネライト] (1996). Shizenshugi kara watakushi shōsetsu e [自然主義から私小説へ]. In J. Kubota [久保田淳] (ed.), Iwanami kōza nihon bungakushi (dai 12 kan) 20 seiki no bungaku 1 [岩波講座 日本文学史〈第 12 巻〉20 世紀の文学 1] (93-118). Tokyo [東京]: Iwanami shoken [岩波書店].

Ishibashi, K. [石橋邦俊] (2014). Dazai Osamu “Hashire Merosu” to Schiller “Hitojichi” [太宰治 『走れメロス』とシラー『人質』]. Jōhō kōgaku kenkyūin kiyō 27 [情報工学研究院紀 要 27], 55-77. Kyūshū kōjō daigaku [九 州工 業 大 学 ]. Retrieved from https://www.lib.kyutech.ac.jp/libi/tech-repo/ishibashi27.pdf

Keene, D. (1964). Japanese Writers and Greater East Asia War. The Journal of Asian Studies, 23(2), 209-225. Retrieved from http://www.jstor.org/stable/205133

Lyons, P. I. (1985). The Saga of Dazai Osamu: A Critical Study with Translations. Stanford: Stanford University Press.

O’Brien, J. (1983). Introduction. In Dazai Osamu: Selected Stories and Sketches (1-15). New York: Cornell University East Asia Program.

Raschen, J. F. L. (1919). Earlier and Later Versions of the Friendship-Theme. I "Damon and Pythias." Modern Philology, 17(2), 105-109. Retrieved from http://www.jstor.org/stable/433201

Rimer, J. T. (1978). Modern Japanese Fiction and Its Traditions: an Introduction. Princeton, Guildford: Princeton University Press.

Schiller, F. (1994-1999a). Die Bürgschaft. Virginia Commonwealth University. Retrieved from http://germanstories.vcu.edu/schiller/hostage dual.html

Schiller, F. (1994-1999b). The Hostage. Virginia Commonwealth University. Retrieved from http://germanstories.vcu.edu/schiller/hostage dual.html

Ueda, M. (1976). Modern Japanese Writers: and the Nature of Literature. California: Stanford University Press.

Vardaman, J. M. (1987). Dazai Osamu's “Run, Merus!” and Friedrich Schiller's “Die Bürgschaft". Comparative Literature Studies, 24(3), 243-250. Retrieved from http://www.jstor.org/stable/40246383

Wolfe, A. S. (2014). Suicide Narrative in Modern Japan: The Case of Dazai Osamu. Princeton: Princeton University Press. 